\title{
Bariatric surgery and perioperative anesthesic approach
}

\section{Bariyatrik cerrahi ve perioperatif anestezik yaklaşım}

\author{
Sezgin Bilgin, Yasemin Burcu Üstüin, Ersin Köksal
}

Ondokuz May1s University, Medicine Faculty, Anesthesiology Department, Samsun, Turkey

Corresponding author: Sezgin Bilgin, MD., Ondokuz Mayis University, Medicine Faculty, Anesthesiology Department, Samsun, Turkey

E-mail: sezgin.bilgin@omu.edu.tr

Received/Accepted: September 05, 2019 / April 28, 2020

Conflict of interest: There is not a conflict of interest.

\section{SUMMARY}

Despite healthy lifestyle campaigns and diet programs Obesity is still a global problem. Considering this fact, the increase in obese patients undergoing bariatric surgery is inevitable. Since obesity is affecting many organ systems, the perioperative management of the bariatric surgical patient provides a number of challenges. Preoperative assessment and preparation considering the specific pathophysiology of this patients are important to reduce mortality and morbidity. Anesthesia management and postoperative care should also be performed with consideration of the risks and comorbidities of these patients. This review will focus on the preoperative, peroperative and postoperative anesthesia management of bariatric surgical patients.
\end{abstract}

Keywords: Anesthesia, bariatric surgery,obesity
(ID) Sezgin Bilgin

(ID) Yasemin Burcu Üstün

(iD) Ersin Köksal

ORCID IDs of the authors:

S.B. 0000-0002-3031-8488

Y.B.Ü. 0000-0002-2628-7543

E.K. 0000-0003-1780-151X

\section{ÖZET}

Obezite, sağlıklı yaşam kampanyaları ve diyet programlarına rağmen küresel bir sorun olmayı sürdürmektedir. Bu gerçek gözönünde bulundurulduğunda bariyatrik cerrahi geçirecek hastaların da artması kaçınılmazdır. Obezite birçok organ sistemini etkilediğinden, bariyatrik cerrahi hastalarının perioperatif yönetimi birtakım zorluklar taşır. Hasta grubunun kendine özgü patofizyolojisi düşünüldüğünde, operasyon öncesi değerlendirme ve hazırlık, mortalite ve morbiditeyi azaltmada oldukça önemlidir. Anestezi yönetimi ve postoperatif bakım da eşlik eden komorbiditeler ve hastaların taşıdıkları riskler gözetilerek uygulanmalıdır. Bu yazıda bariyatrik cerrahi hastalarının ameliyat öncesi, ameliyat sırasında ve ameliyat sonrası dönemlerdeki anestezi yönetimi üzerinde durulacaktır.

Anahtar sözcükler: Anestezi, bariyatrik cerrahi, obezite 


\section{INTRODUCTION}

The increasing in the size of the obese population in the world is urging health institutions to take serious measures and to initiate broad campaigns against obesity. According to the 2016 statistics released by the World Health Organization (WHO), the ratio of the adult population with a body mass index (BMI) of above 30 in Turkey approaches to $30 \%$. Considering this increase in the number of obese people despite healthy lifestyle campaigns and diet programs, it is not surprising that surgical treatment of obesity is getting more common. The term bariatric is derived from the Greek term 'bar' which means weight and the 'iatr' which refers to the treatment. The term refers to the method of surgery that modifies the anatomy of the digestive system and limits the amount of food ingested or digested and thus provides weight loss. The first procedure for the surgical treatment of obesity is jejunoileal bypass in 1954. Roux-en-Y gastric bypass and vertical banded gastroplasty were introduced in 1967 by Dr.Edward E. Mason.

\section{Bariatric Surgery}

Gastric bypass is primarily mediated by neurohormonal modulation of hunger, insulin metabolism, and sensitivity. Today it is one of the most widely used procedures. The vertical banded gastroplasty was replaced by an adjustable gastric band over time.

Malabsorptive Bariatric Procedure is another one that is performed by Nicola Scopinaro in 1976. Adjustable gastric band was introduced in Europe in 1990, while laparoscopic sleeve gastrectomy was introduced by Dr. Michel Gagner in 2002 as a stand-alone procedure.

The four different bariatric surgical procedures currently in use have the potential to improve the health and well-being of the patient by providing significant and sustainable weight loss. There are differences in the way in which each method is applied, the mechanism of action and the results.

Adjustable gastric band: In this procedure, an adjustable silicone band is placed in the upper part of the stomach and a pouch of 15-20 milliliters is formed. In this way, food intake is restricted. Weight loss from 40 to $60 \%$ can be achieved with the gastric band. Because weight loss is provided by restrictive method, anemia and vitamin deficiencies may be seen in some bariatric procedures. The 30-day mortality rate is $0.1 \%$. Reported common complications are the displacement of the band, gastric erosion, and pouch dilatation. The risk of band erosion is 1 to $2 \%$ and the risk of slip is 2 to $4 \%$.

Roux-en-Y gastric bypass: It is the most commonly used weight loss procedure in the United States of America. It has both restrictive and malabsorptive effects. The stomach is divided into a 15 to 30 milliliter pouch, and the rest of the stomach is separated or removed from the intestinal tract. The created pouch jejunuma is connected with Rouxen-Y gastrojejunostomy. With this method, patients may lose up to $50 \%$ of excess weight. Mortality ranges from $0.3 \%$ to $1.6 \%$. The 30 -day mortality rate is below $1 \%$. Deep venous thrombosis, pulmonary embolism and gastrointestinal leakage are among serious complications. Long-term complications are anemia and vitamin-mineral deficiencies. The serum levels of iron, folate and vitamin B12 should be closely monitored in many patients as they may require lifelong support.

Biliopancreatic diversion: This is a predominantly malabsorptive procedure and results in much more malabsorption than gastric bypass. Partial gastrectomy consists of anastomosing the remaining part of the stomach to the distal ileum. A common canal is formed at 50 to 100 centimeters from the ileocecal valve by anastomosing the proximal ileum to terminal ileum. The absorption of food takes place only in this common channel, and this is the first place where food is mixed with bile and digestive enzymes along the intestinal tract. Partial gastrectomy is thought to reduce weight gain by limiting food intake and intestinal bypass is expected to continue weight loss secondary to malabsorption. It is reported that excessive weight loss can reach up to $72 \%$. 30-day mortality is $1.1 \%$. Serious complications are malnutrition and severe vitamin deficiency. Complications can be limited by extending the common channel.

A variant of biliopancreatic diversion is the biliopancreatic diversion with the duodenal switch. In this procedure, the first part of the duodenum is left intact. In this way the incidence of stomal ulcers and dumping is reduced. The procedure involves a sleeve gastrectomy in which the antrum, the pylorus and the duodenum are left intact. While the distal ileum is anastomosed to the duodenum, the proximal ileum is anastomosed to the terminal ileum and the ileocecal valve is formed in a common channel at a distance of approximately 50 to 100 centimeters. Vitamin protein monitoring is important in long term patient follow-up.

Sleeve gastrectomy: In this procedure, the large curvature of the stomach is excised to leave a 
tubular section along the small curvature. This method leads to an early feeling of fullness and reduced appetite as a result of gastric restriction. Weight loss ranges from $40 \%$ to $50 \%$. Sleeve gastrectomy was initially identified as the first step of biliopancreatic diversion with duodenal switch. However, some patients preferred the second procedure because they were very satisfied with the results of sleeve gastrectomy and this increased the interest in the application of sleeve gastrectomy as a primary procedure. Increasing literature results place sleeve gastrectomy somewhere between band and bypass in terms of complications and results. There is also a concern that the remaining gastric fragment may expand over time and cause weight loss failure and may necessitate a second bariatric procedure such as an adjustable gastric band, gastric bypass or biliopancreatic diversion ${ }^{2}$.

\section{Perioperative Anesthesic Approach}

\section{Preoperative Evaluation}

Before the surgery, the patient should be evaluated by a multidisciplinary team of endocrinologist, dietician, psychiatrist, surgeon and anesthesiologist. This evaluation is important in terms of surgical decision making and preparation of peroperative care. The history of diet and appetite suppressive drug use should be assessed. Obesity may be accompanied by respiratory, cardiovascular, endocrine, gastrointestinal, musculoskeletal disorders, various types of cancers, protein and vitamin deficiencies or electrolyte disturbances.

Cardiovascular System: Since blood volume, cardiac output, ventricular workload and myocardial oxygen $(\mathrm{O} 2)$ consumption increase in these patients, systemic hypertension (HT), pulmonary HT, ischemic heart disease, heart failure, and right or left ventricular hypertrophy should be evaluated and the Electrocardiogram (ECG) findings, if any, should not be disregarded. In obese patients, dilatation and hypertrophy triggered by increased blood volume causes a decrease in left ventricular compliance. Impaired ventricular filling and increased end-diastolic pressure facilitate diastolic dysfunction. In addition, fat infiltration of myocardial fibers, including the conduction system, results in arrhythmia ${ }^{3}$.

Respiratory system: The pressure on the abdominal muscles towards the diaphragm and fat tissue in the chest wall decreases the compliance of the respiratory system in obese patients. An increase in the respiratory system and airway resistance leads to closure of small airways in low lung volumes. Fat tissue reduces the ability of the chest and pulmonary parenchyma to expand, resulting in a reduction in expiratory reserve volume (ERV) and functional residual capacity (FRC).

The FRC may remain in the morbid obese patient below the closure capacity (CC). This may cause small airways closure, ventilation/perfusion mismatch, right-to-left shunt, and hypoxemia. Supine position, trendelenburg position, general anesthesia, and muscle relaxants contribute to hypoxia..

Obesity is considered a major risk factor for sleep disorder syndromes such as obstructive sleep apnea (OSA) and obesity hypoventilation syndrome. Sleep disorder syndromes with obstructive sleep apnea can be observed up to $70 \%$ of patients planned for bariatric surgery and obesity hypoventilation syndrome can be observed in $88 \%$ of them ${ }^{4}$. In order to eliminate the possibility of overlooking undiagnosed OSA syndrome, there are opinions suggesting that all patients with BMI> 40 should undergo polysomnography ${ }^{5}$. However, it is recommended that the surgeon and the anesthesiologist decide together for the necessity of polysomnography in the patient who is considered as having OUA syndrome in the preoperative evaluation in the ASA guidelines ${ }^{6}$. The STOPBang (Table 1.) test can be used for the detection of OSA at the preoperative visit because it is simple and sensitive $(95-100 \%)^{7}$. 
Table 1: STOP-BANG Score for Obstructive Sleep Apnea

\begin{tabular}{|l|l|l|}
\hline STOP & & \\
\hline Do you SNORE loudly? & Yes & No \\
\hline $\begin{array}{l}\text { Do you often feel TÍRED, fatigued, or sleepy } \\
\text { during the daytime? }\end{array}$ & Yes & No \\
\hline $\begin{array}{l}\text { Has anyone OBSERVED you stop breathing } \\
\text { during sleep? }\end{array}$ & Yes & No \\
\hline $\begin{array}{l}\text { Do you have (or being treated for) high blood } \\
\text { PRESSURE? }\end{array}$ & Yes & No \\
\hline BANG & Yes & No \\
\hline $\begin{array}{l}\text { Patient Body Mass Index? } \\
\leq 35 \mathrm{~kg} / \mathrm{m} 2,>35 \mathrm{~kg} / \mathrm{m} 2\end{array}$ & Yes & No \\
\hline $\begin{array}{l}\text { Patient AGE? } \\
\leq 50 \text { years old, }>50 \text { years old }\end{array}$ & Yes & No \\
\hline $\begin{array}{l}\text { Patient NECK circumference? } \\
\leq 40 \mathrm{~cm},>40 \mathrm{~cm}\end{array}$ & Yes & No \\
\hline $\begin{array}{l}\text { Patient GENDER? } \\
\text { Female/ Male }\end{array}$ & \multicolumn{2}{|l|}{} \\
\hline
\end{tabular}

High risk of OSA: Yes 5 - 8

Intermediate risk of OSA: Yes $3-4$

Low risk of OSA: Yes 0 - 2

Another important issue in these patients is airway management. Although increase in BMI poses an increased risk for intubation difficulty ${ }^{8}$, this difficulty is not a risk factor for laryngoscopy ${ }^{9}$. The anesthesiologist should be alert to the preoperative visit for the signs of intubation difficulties. The neck circumference of $43 \mathrm{~cm}$ in men and $41 \mathrm{~cm}$ in women is an important marker for intubation difficulty ${ }^{10}$.

In preoperative visit, premedication with sedative or hypnotic drugs is not recommended in the morbidly obese patient ${ }^{11}$.

Risk of thrombosis: Obesity is a prothrombotic condition and thrombotic diseases such as myocardial infarction, stroke, and venous thromboembolism (VTE) are associated with increased morbidity and mortality ${ }^{12}$. The incidence of postoperative VTE may be up to 10 times higher in obese women compared to normal weight ones 13. The susceptibility to coagulation may be extended to the second week postoperatively depending on the type of surgery and the patient's BMI ${ }^{14}$. Factors such as prolonged immobilization, DM, hypercholesterolemia, and polycythemia contribute to thrombus formation. For this reason, postoperative early mobilization should be tried and measures such as anticoagulant therapy should be considered.

In obese patients, insulin resistance and diarrhea are common and strict glucose control is important in the perioperative period.

Gastroesophageal reflux is common among these patients. Gastric secretion volumes are increased, gastric $\mathrm{pH}$ decrease, and gastroparesis is delayed. Considering the high intra-abdominal pressure, the risk of aspiration is higher ${ }^{15}$.

\section{Intraoperative Period}

Positioning and Monitoring: Combination of two operation beds can be considered if there are no bed specially designed for obese patients. These patients, especially those with a history of diabetes, are sensitive to pressure sores. Pressure points should be supported by pads to prevent nerve damage and pressure wounds. The brachial plexus and sciatic nerve may be exposed to stresses due to position and pressure to create ischemia in the nerve. The position in obese patients is also important for lung mechanics. In the supine position, FRC decreases, perfusion equality of ventilation deteriorates and shunts occur. Increased fat mass in the thorax causes a decrease in ERV. 
Increased airway resistance and reduced respiratory system compliance (increased pulmonary blood volume reduces lung compliance, increased adipose tissue reduces thoracic compliance) increases breathing workload. When FRC falls below the closing capacity, it results in the closure of small airways and alveoli, even in spontaneous breathing. Hypoxemia is common in obese patients due to these changes. Supine position, trendelenburg position, general anesthesia, and muscle relaxants deepen hypoxemia. Recruitment maneuver, the application of Peep, and head up position are maneuvers that help correct the hypoxemia. It is recommended that the patient should be 30-40 degrees up and over in the peroperative period after the patient is taken to the operation bed unless the surgical necessity requires to do otherwise ${ }^{11}$. In this position, the load on the diaphragm decreases, respiratory system compliance increases, and FRC increases.

Although obese patients are recommended to have a standard monitorization including blood pressure, ECG, oxygen saturation, and EtCO2, there may not be a suitable size of head for blood pressure measurement. In this case, hand or ankle may be used as a measuring site or invasive artery monitoring may be preferred. In addition, recovery from the effect of muscle relaxants should be monitored by TOF monitoring.

Pharmacology: In anesthesia applications, the drug dose is calculated by evaluating the patient's weight, age and clinical conditions. Drug dose in obese individuals is affected by many factors such as increased body fat, decreased total body water, changes in protein binding, increased blood volume and cardiac output, increased lipid concentrations in the blood, organomegaly, increased phase II reactions (glucuronidation and sulphation), and absorption. The distribution volume of the lipophilic drugs increases. In addition, changes in total blood volume and cardiac output also change the pharmacokinetics of drugs. Most of the anesthetic drugs are lipophilic and the distribution volume ( $\mathrm{Vd}$ ) of drugs such as barbiturate and benzodiazepine increased in obese patients compared to non-obese patients. However, recent evidence indicates that generalization is difficult, and the volume of distribution is drugspecific. In order to calculate the correct and effective drug dose, formulas were developed considering the weight, height and gender of the patient (Table 2) (3). In obese patients, loss of consciousness develops after a single bolus dose based on lean body weight (LBW), but redistribution of the drug from the central compartment to adipose tissue may result in awareness. In terms of awareness, thiopental carries more risk than propofol. If the single bolus dose is made according to total body weight (TBW), hypotension is seen along with longer duration of action. Therefore, after anesthesia induction according to LBW, either maintenance anesthetic drug should be started without delay or additional bolus dose should be applied to prevent awareness ${ }^{16}$. Because the clearance is the primary determinant when calculating the maintenance drug dose, the maintenance infusion dose of propofol is calculated according to TBW. Because obesity increases plasma cholinesterase level and activity, succinylcholine dose is calculated according to TBW. The pharmacokinetics of modern volatile agents are not affected by obesity and can be used safely ${ }^{17}$. The recommended dosage calculation formulas for drugs used in anesthesia applications are given in Table $3^{3,19,20}$.

Tablo 2: Formulas used for calculating drug dosages

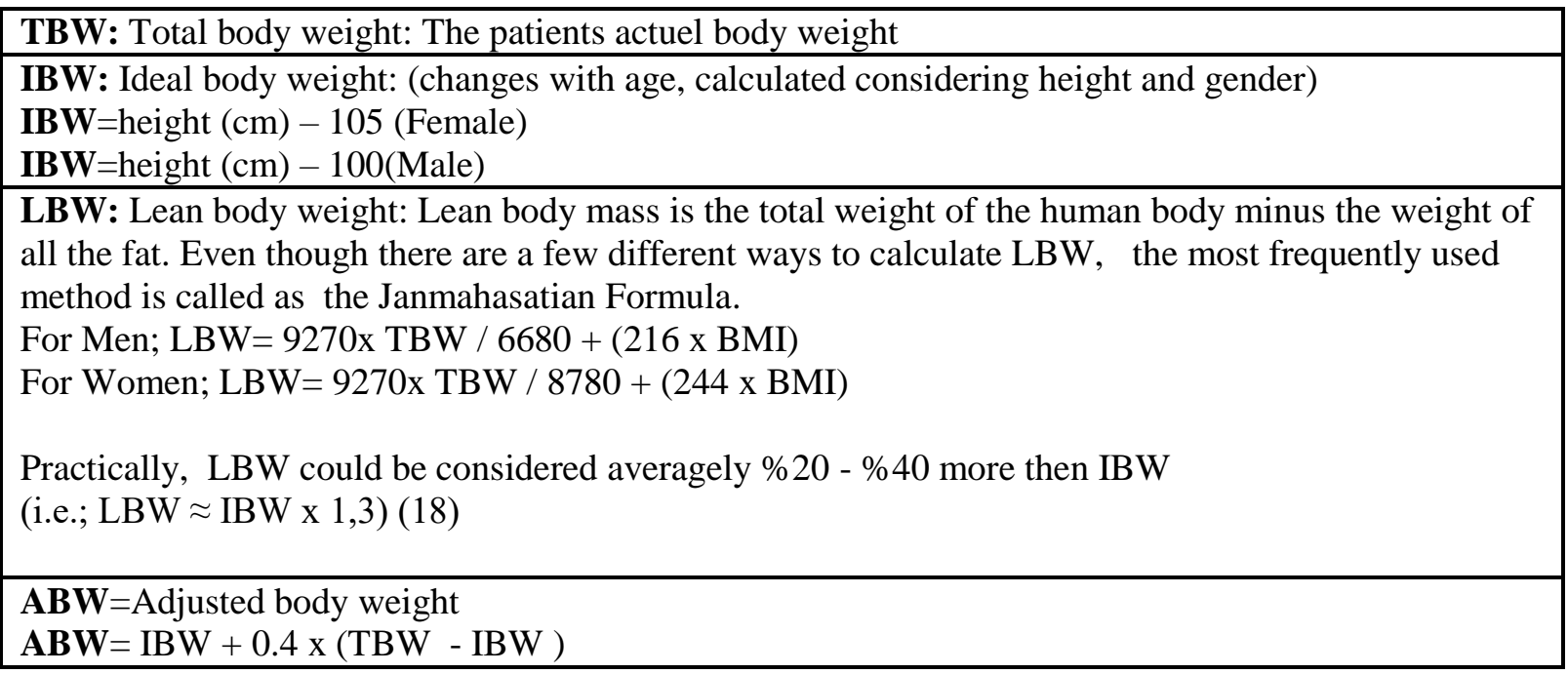


Tablo 3: Dosing for frequently apllied drugs during anesthesia management

\begin{tabular}{|c|c|c|c|c|}
\hline & TBW & LBW & IBW & ABW \\
\hline $\begin{array}{l}\text { Anesthesia } \\
\text { induction }\end{array}$ & & $\begin{array}{l}\text { Propofol } \\
\text { Thiopental }\end{array}$ & & \\
\hline $\begin{array}{l}\text { Anesthesia } \\
\text { maintenance }\end{array}$ & $\begin{array}{l}\text { Propofol } \\
\text { Thiopental }\end{array}$ & & & \\
\hline Analgesics & & $\begin{array}{l}\text { Fentanyl } \\
\text { Remifentanil } \\
\text { (infusion) } \\
\text { Morphine } \\
\text { Paracetamol } \\
\end{array}$ & & $\begin{array}{l}\text { Sufentanil } \\
\text { Alfentanil }\end{array}$ \\
\hline $\begin{array}{l}\text { Neuromuscular } \\
\text { blockers }\end{array}$ & Succinylcholine & & $\begin{array}{l}\text { Rocuronum } \\
\text { Vecuronium } \\
\text { Atracurium }\end{array}$ & \\
\hline Local Anesthetics & & $\begin{array}{l}\text { Bupivacaine } \\
\text { Lidocaine }\end{array}$ & & \\
\hline Other drugs & Dexmedetomidine & Ketamine & & $\begin{array}{l}\text { Sugammadex } \\
\text { Neostigmine } \\
\text { (maximum 5mg) } \\
\text { Antibiotics } \\
\text { LMWH }\end{array}$ \\
\hline
\end{tabular}

TBW: Total body weight

LBW: Lean body weight

IBW: Ideal body weight

ABW: Adjusted body weight

LMWH: Low Molecular Weight Heparin, mg: miligram

General anesthesia and ventilation strategies: Increased neck circumference and mallampati scoring are the most important markers of intubation in obese patients. The head, neck, and shoulders are supported by a ramp position, which allows the jaw space from the chest wall and brings the ear external meatus and the sternal notch in the same plane to facilitate laryngoscopy and intubation. A rapid serial induction should be done with cricoid compression to reduce the risk of aspiration after preoxygenation in the upward position.

In obese patients, PEEP $(10 \mathrm{cmH} 2 \mathrm{O}$ recommended over $5 \mathrm{cmH} 2 \mathrm{O}$ ) is useful in preventing atelectasis after anesthesia induction. This high and continuous positive pressure at the end of expiration opens the closed alveoli and allows reexpansion of the atelectatic sites. When PEEP is co-administered with high tidal volume, it worsens hypoxemia by reducing cardiac output and $\mathrm{O} 2$ presentation to tissues. Ventilation parameters should be adjusted to tissues by considering oxygen delivery, hypoxia, and hemodynamics. Lung protective ventilation should be conducted while avoiding baro-trauma and volu-trauma. Adjusting the tidal volume according to the ideal body weight (IBW) to $6-8 \mathrm{mg} / \mathrm{kg}$ and venting with the lowest $\mathrm{FiO} 2$ with $\mathrm{O} 2$ saturation> $90 \%$ are suitable strategies for these patients. PressureControlled Ventilation Volume-Guaranteed (PCVVG) mode can be preferred ${ }^{21}$. At the same time, the 'recruitment' maneuver, which is the most effective method for increasing the partial $\mathrm{O} 2$ pressure (PO2), can be applied at intervals in obese patients. In hemodynamically stable patients, extubation should be performed in 30-40 degrees up position.

Fluid Treatment: Appropriate fluid treatment to provide effective perfusion and oxygenation without causing volume burden is also essential in obese patients similar to the regular patients. In addition, adequate venous return and left ventricular filling pressure in morbidly obese patients are very important for perioperative cardiovascular stability. However, there is no consensus on which liquid regime should be used. In these operations, which are usually performed laparoscopic, parameters such as mean blood pressure, central venous pressure or urine volume are not helpful in predicting fluid status. Intraoperative fluid regimen is recommended according to IBW. Hypovolemia increases the incidence of postoperative nausea and vomiting as well as hemodynamic effects. Therefore, it is important to individualize the liquid regimen in obese patients, to ensure normovolemia in the 
preoperative period and to maintain this in the postoperative period ${ }^{22,23,24}$.

Regional anesthesia: Although regional anesthesia is preferred over general anesthesia in appropriate patients, preparation for airway management should be done ${ }^{3}$. Regional anesthesia techniques have a higher risk of failure in obese patients. The length of the spinal or epidural needles may be short and special material preparation may be required. Ultrasonography is helpful in regional techniques. If sedation is required, this should be kept at minimum. The position is advantageous in terms of both the comfort of the patient and the success of the operator. Inclination to the practitioner on the bed where the patient is sitting makes the patient lean forward in a reflex and facilitates the procedure. It is recommended to leave a catheter of at least $5 \mathrm{~cm}$ in the epidural space to reduce epidural catheter migration ${ }^{25}$. In regional anesthesia, it is safer to calculate the local anesthetic drug dose using LBW. Despite the potential reduction in neuro-axial volume due to adipose tissue, standard local anesthetic doses are recommended for central blocks ${ }^{3}$.

\section{Postoperative Period}

Careful follow-up should be continued to ensure patient safety after surgery. For this purpose, adequate analgesia, prevention of nausea and vomiting, continuation of DVT prophylaxis, follow-up of breathing pattern, $\mathrm{O} 2$ support, and pulse oximetry monitoring should be performed. In the postoperative period, the continuation of the head position up to 30-45 degrees is recommended. If the patient is using CPAP at home and if adequate oxygen saturation levels cannot be achieved with inhaled oxygen (if $\mathrm{PaO} 2 / \mathrm{FiO} 2$ ratio $<300$ ), postoperative CPAP/BIPAP should be performed. Although CPAP may not be associated with surgical complications such as anastomotic leakage in the past ${ }^{26,27}$, gastric insufflation and distension should be considered in the possibility of difficulty in anastomotic line ${ }^{18}$. Early spirometric exercises, especially in patients with OSA, accelerate the recovery of preoperative pulmonary functions. Early mobilization and analgesia contribute to reducing postoperative respiratory complications. ${ }^{21,28}$

In addition, phlebotrombosis may develop as a result of prolonged immobilization in these patients and thromboembolism is an important cause of postoperative mortality.

Patients with the instable cardiovascular system and the risk of postoperative arrhythmia should be monitored by ECG monitoring.
A rare but serious complication of obese patients is rhabdomyolysis. In addition to obesity, risk factors include hypotension, immobilization, long operation times, and dehydration. The patient should be suspected of rhabdomyolysis in the postoperative period, if there is pain especially in the hips. In this case, serum creatinine kinase concentration should be measured rapidly and high values, aggressive fluid resuscitation, diuretics, and urinary alkalization should be taken to prevent further acute kidney injury ${ }^{3}$.

Optimal analgesia contributes to the improvement of lung mechanics by facilitating respiratory effort and decreasing postoperative respiratory infections ${ }^{29}$. The multimodal analgesia regimen is ideal for pain control. According to this, IV acetaminophen, NSAIDs and tramadol can be used at regular intervals if there is no contraindication ${ }^{30}$. Nonselective NSAIDs are not recommended due to the risk of gastric perforation. Ketorolac alone or in combination with local anesthesia provides significant improvement in postoperative pain ${ }^{31,32}$.

The local anesthesia injection performed by the surgeon to the wound or rectus sheath is useful. Although opioid use is avoided in obese patients, patient-controlled analgesia (PCA) with postoperative fentanyl may be used in monitorized patients without a sleep disorder. Adjuvants such as ketamine, dexmedetomidine, and pregabalin may be added to the treatment. The limiting factors for ketamine in obese patients are severe arterial hypertension and heart failure simultaneously, but it is not possible to induce hypertension with low dose $\left(8-10 \mathrm{mg} / \mathrm{h}\right.$ infusion) ketamine ${ }^{33}$. Dexmedetomidine is a good option for analgesia and sedation, but also reduces the need for opioids, thus contributing to a reduction in the incidence of postoperative nausea and vomiting ${ }^{34}$. It has been reported that cardiovascular side effects are minimal at low dose $(0.2 \mathrm{mcg} / \mathrm{kg} / \mathrm{h})$ dexmedetomidine infusion without loading dose ${ }^{35}$.

Bariatric surgery procedures are emetogenic because they interrupt the mechanism of intestinal peristalsis and gastroesefagial antireflux. In addition, the fact that most of the patient group is female and the laparoscopic operation generally increases the incidence of postoperative nausea and vomiting (PONV). PONV and gag reflex may cause difficulty in anastamosis suture line, and may even cause gastric prolapse in gastric band surgery. Adequate hydration is effective in preventing nausea, but excessive fluid loading can also be done in PONV. Instead of inhalation agents and nitrous oxide, propofol and TIVA may be preferred. Combined therapy is the most effective 
method in antiemetic prophylaxis. Drug groups used for this purpose are 5HT3 receptor antagonists, glucocorticoids, butyrophenone group drugs, neurokinin-1 receptor antagonists, antihistamines, anticholinergics and phenothiazines. The dose and administration time of some antiemetic drugs are given in table 4 . The need for individualization of treatment is also valid here. For example, dexamethasone is considered to be relative contraindicative in diabetic patients since hyperglycemia may be seen in the postoperative 12 hours after dexamethasone use. 5HT3 receptor antagonists (especially ondansetron) may cause prolongation or increase in $\mathrm{PR}, \mathrm{QRS}, \mathrm{QT} / \mathrm{QT} \mathrm{c}$ in ECG and should be used with caution. Given the effect of droperidol and haloperidol on QT, combination with ondansetron will not be a safe choice. It may be an appropriate approach to use 5HT3 receptor antagonists and steroid group drugs together ${ }^{36}$.

Table 4: The dose and administration time of antiemetic drugs.

\begin{tabular}{|c|c|c|}
\hline \multirow{6}{*}{$\begin{array}{l}\text { 5HT3 receptor } \\
\text { antagonists; }\end{array}$} & Dose & Administration time \\
\hline & Ondansetron $4-8 \mathrm{mg}$ & End of surgery \\
\hline & Dolasetron 12.5 İV & End of surgery \\
\hline & $\begin{array}{l}\text { Granisetron } 0.35-3 \\
\mathrm{mg} \text { IV }(5-20 \mathrm{mcg} / \mathrm{kg})\end{array}$ & End of surgery \\
\hline & Tropisetron $2 \mathrm{mg}$ IV & End of surgery \\
\hline & $\begin{array}{l}\text { Palonosetron } \\
0.075 \mathrm{mg} \text { IV }\end{array}$ & Induction \\
\hline \multirow[b]{2}{*}{ Steroids } & Dexamethasone 4-5mg & Induction \\
\hline & $\begin{array}{l}\text { Methylprednisolone } \\
40 \text { mg IV }\end{array}$ & \\
\hline \multirow[t]{2}{*}{ Butyrophenone group } & $\begin{array}{l}\text { Haloperidol0.5- } 2 \mathrm{mg} \\
\text { IM veya IV, } \\
\text { (QT prolongstion) }\end{array}$ & $\begin{array}{l}\text { Induction/ End of } \\
\text { surgery }\end{array}$ \\
\hline & 0.625 to $1.25 \mathrm{mg}$ IV & End of surgery \\
\hline $\begin{array}{l}\text { Neurokinin-1 receptor } \\
\text { antagonists }\end{array}$ & $\begin{array}{l}\text { Aprepitant } \\
(40 \text { and } 80 \mathrm{mg})\end{array}$ & Induction \\
\hline
\end{tabular}

\section{CONCLUSION}

In conclusion, as the anesthesia and surgical risk are higher in obese patients, anesthetists should be familiar with the clinical follow-up of obese patients in all surgeries, especially in bariatric procedures. Although there is no consensus on perioperative care of these patients, a good preoperative evaluation contributes to the correct management of the patient during the peroperative period. Careful and individualized intraoperative and postoperative follow-up helps prevent complications in this patient group with high comorbidity.

\section{REFERENCES}

1. Taşkın M, Zengin SÜ, Taşkın HE, Bariyatrik ve Metabolik Cerrahinin Tarihçesi, Turkiye Klinikleri J Gen Surg-Special Topics. 2015;8(3):1-5.

2. Buchwald H. The Evolution of Metabolic/Bariatric Surgery. Obes Surg 2014; 24: 1126-1135

3. Nightingale CE, Margarson MP, Shearer E, et al. Association of Anaesthetists of Great Britain; Ireland Society for Obesity and Bariatric Anaesthesia. Peri-operative management of the obese surgical patient $2015 \mathrm{Jul} ; 70: 859-76$.

4. Frey WC \&Pilcher J. Obstructivesleep-related breathing disorders in patients evaluated for bariatric surgery. Obesity Surgery 2003; 13: 676683.

5. Hallowell PT, Stellato TA, Schuster M et al. Potentially life-threatening sleep apnea is 
unrecognized without aggressive evaluation. AmericanJournal of Surgery2007; 193: 364-367.

6. ASA guidlines OSA Practice Guidelines for the Perioperative Management of Patients with Obstructive Sleep Apnea: An Updated Report by the American Society of Anesthesiologists Task Force on Perioperative Management of Patients with Obstructive Sleep Apnea. Anesthesiology 2014;120(2):268-286

7. Acar HV, Kaya A, Yucel F, et al. Obstruktif Uyku Apnesi Tarama Testi Olarak Kullanılan STOP-Bang Testinin Turk Populasyonunda Gecerliliğinin Saptanması Turk J Anaesth Reanim 2013; 41: 115-20.

8. Juvin P, Lavaut E, Dupont H, et al. Difficult tracheal intubation is more common in obese than in lean patients. Anesth Analg. 2003;97(2):595600.

9. Ezri $T$, MedalionB,Weisenberg $M$, et al. Increased Body mass index per se is not a predictor of difficult laryngoscopy. Can J Anaesth. 2003;50(2):179-83.

10. Kristensen MS. Airway management and morbid obesity.Eur J Anaesthesiol 2010;27:923927.

11. Yao, F.-S.F.. (2012). Yao \& Artusio's anesthesiology: Problem-oriented patient management: Seventh edition.

12. Blokhin IO, Lentz SR. Mechanisms of thrombosis in obesity. Current Opinion in Hematology 2013; 20: 437-44.

13. Parkin L, Sweetland S, Balkwill A, Green J, Reeves G, Beral V. Body massindex, surgery, and risk of venous thromboembolism in middle-aged women: a cohort study. Circulation 2012; 125 : 1897-904.

14. Magee CJ, Barry J, Javed S, Macadam R, Kerrigan D. Extended thromboprophylaxis reduces incidence of postoperative venous thromboembolism in laparoscopic bariatric surgery. Surgery for Obesity and Related Diseases 2010; 6:322-5.

15. Schumann R, Anaesthesia for bariatric surgery. Best Practice\&Research Clinical Anaesthesiology 2011; 25: 83-93.

16. Hanley MJ, Abernethy DR, Greenblatt DJ. Effect of obesity on the pharmacokinetics of drugs in humans. Clinical Pharmacokinetics 2010; 49: 71-87.

17. De Baerdemaeker LEC, Mortier EP, Struys MMRF. Pharmacokinetics in obesepatients.
ContinuingEducation in Anaesthesia, Critical Care\&Pain 2004: 4; 152-155.

18. Soleimanpour H, Safari S, Sanaie S, Nazari M, Alavian SM.

Anesthetic Considerations in Patients Undergoing Bariatric Surgery: A Review Article. Anesth

Pain Med. 2017 Jul 11;7(4):e57568.

19. Ingrande J, Lemmens

HJ.

Dose adjustment of anaesthetics in

the morbidly obese. Br J Anaesth. 2010;105 Suppl 1:i16-23.

20. Leykin Y, Miotto L, Pellis T. Pharmacokinetic considerations in the obese. Best Practice\&Research Clinical Anaesthesiology 2011; 25: 27-36.

21. Fernandez-Bustamante A, Hashimoto S, Serpa Neto A, et al. Perioperative lung protective ventilation in obese patients. BMCAnesthesiol. 2015;15:56.

22. Pösö T, Kesek D, Aroch R, Winsö O. Morbid Obesity and Optimization of Preoperative Fluid Therapy. Obesity Surgery 2013; 23: 1799-1805.

23. Pösö T, Kesek D, Aroch R, WinsöO. Rapid weightloss is associated with perioperative hypovolemia in morbidly obese patients.ObesSurg . 2013; 23: 306-13.

24. PösöT, WinsöO, ArochR, KesekD. Perioperative fluid guidance with transthoracic echocardiography and pulse contour device in morbidly obese patients. Obes Surg. 2014; 24:2117-25.

25. Brodsky JB, Mariano ER. Regional anaesthesia in the obese patient: Lost landmarks and evolving ultrasound guidance. Best Pract Res Clin Anaesthesiol. 2011; 25: 61-72.

26. Huerta S, DeShields S, Shpiner R, et al. Safety and efficacy of postoperative continuous positive airway pressure to prevent pulmonary complications after Roux-en-Y gastric bypass. Journal of Gastrointestinal Surgery 2002; 6: 354358.

27. Ramirez A, Lalor PF, Szomstein S, Rosenthal J. Continuous positive airway pressure in the immediate postoperative period after laparoscopic Roux-en-Y gastric bypass: is it safe? Surgery for Obesity and Related Diseases2009; 5: 544-546.

28.Thorell A, MacCormick AD, Awad S, et al. Guidelines for Perioperative Care in Bariatric Surgery: Enhanced RecoveryAfter Surgery (ERAS) Society Recommendations. World J Surg 2016; 40:2065-2083. 
29.Porhomayon J, Leissner KB, El-Solh AA, Nader ND. Strategies in Postoperative Analgesia in the Obese Obstructive Sleep Apnea Patient. Clin J Pain2013;29:998-1005.

30.Schug

SA, Raymann

A.

Postoperativepain management of

the obese patient. Best Pract Res Clin Anaesthesiol. 2011; 25.73-81.

31.Govindarajan R, Ghosh B, Sathyamoorthy MK, et al. Efficacy of ketorolac in lieu of narcotics in the operative management of laparoscopic surgery for morbid obesity. Surgery for Obesity and Related Diseases 2005; 1: 530-535.

32. Kamelgard J. Combined preemptive and preventive analgesia for opengastric bypass compares favorably with postoperative painfollowing laparoscopic accessforthesamesurgery. Obesity Surgery 2006; 16: 807-808.
33.Visser E, Schug SA. The role of ketamine in pain management. Biomed Pharmacother 2006; 60: 341-348.

34.Singh PM, Panwar R, Borle A, et al. Perioperative analgesic profile of dexmedetomidine infusions in morbidly obese undergoing bariatricsurgery: a meta-analysis and trial sequential analysis. Surgery for Obesity and Related Diseases 2017; 13: 1434-1448.

35.Tufanogullari B, White PF, Peixoto MP, et al. Dexmedetomidine infusion during laparoscopic bariatricsurgery: the effect on recovery outcome variables. AnesthAnalg. 2008; 106: 1741-8.

36.Gan TJ, Diemunsch P, Habib AS, et al. Society for Ambulatory Anesthesia. Consensus guidelines for the management of postoperative nausea and vomiting. Anesth Analg 2014; 118: 85-113. 